gold was expected to be ready for production by the end of the year. The preparation of organic compounds labelled with carbon-14 has boen continued, and some fifteen compounds are now availakle. In the autumn of 1952 a regular consultative service was started by the Isotope Department for Norwegian industry, and details of the various industrial firms and the investigations undertaken with the particular isotopes used are listed in the annual report.

The final sections of the report deal briefly with reactor development; health physies; the informa. tion service and its publications ; the accounts of the Establishment for the period July 1, 1952-June 30, 1953 ; the personnel in the various departments; and the various scientific mcetings and conferences attended by members of the staff of the Establishment during the period under review.

\section{BRITISH HYDROMECHANICS RESEARCH ASSOCIATION}

\section{ANNUAL REPORT FOR 1952-53}

$\mathrm{T}$

HE sixth annual report of the British Hydromechanics Research Association, covering the period October 1952-September 1953*, records satisfactory development in both the activities and finances of the Association. Although the scale of operation is modest, it is stated that the Association's technical prestige has risen considerably and that it is being consulted as an authority on fluid mechanies by a widening range of industries.

The first five-year period of government grant-aid expired at the end of the year under review, and an application for its continuation and augmentation submitted to the Industrial Grants Committee was roceived sympathetically. However, the new grant, although rising to a higher maximum than the original, is not so favourably proportioned; for the first $£ 18,000$ of income the grant is $£ 9,000$ and then $£ 75$ per $£ 100$ up to a maximum additional grant of $£ 9,000$. It is expected that subscriptions from present members for 1953-54 will exceed the minimum grant-earning figure.

The two visitors to the Association, Brigadier R. A. Bagnold and Prof. L. Rosenhead, appointed by the Department of Scientific and Industrial Research, continued to take a keen interest in the activities of the Association and to attend meetings of the Council and research committees. During the year the constitution of these committees was revised, and those formerly dealing with fundamental fluid mechanics, instruments, and pipe-flow problems were combined into a single committee dealing with non-machinery problems, while the other research committees were enlarged. Details of these committees, together with a list of their members, and of the ordinary and associate members of the Association, are given in the report.

The staff of the Association has been increased and now numbers thirty-three, the senior staff consisting of the diroctor of research, Mr. L. E. Prosser ; the deputy director of research, Mr. R. C. Worster; five research engineers and one junior research engineer; the secretary and the librarian. From the

* British Hydromechanics Research Association. Sixth Annual Report, October 1952 to September 1953. Pp. 26. (From the Association, Nettleswell Road, Harlow, Essex.) research work undertaken since the Association's laboratory was opened in 1951, much useful information has emerged, particularly in relation to sump design, pulsating flow metering, pre-rotation in centrifugal pumps and the precision manometer. Some of the more recent work and of the results obtained are briefly described in the annual report. Instruments for the metering of pulsating flows have been successfully developed, and preliminary work with simple suction-pump layouts has been extended to models of actual or proposed installations. The collection and study of data on the friction loss in pipes and fittings have now been completed. A technical note dealing with the pressure surges resulting from a failure of the power supply to a pumping set has recently been published and, as little information is available on the subject, work has been started on an investigation of the rate of gas release from liquids when the pressure is reduced.

There is considerable interest in the hydraulic transport of large coal, and the Association has accordingly undertaken an extensive investigation of the basic hydraulic process involved. The results obtained so far indicate that the hydraulic transport of coal on a large scale should be economic over distances of several miles. A promising application is the vertical transport of coal from the pit bottom or working face to the surface, and the main practical problem of raising the mixture of coal and water to the required pressure is being tackled by the development of a coal feeder for delivering the coal into a pipeline where the water has previously been raised to high pressure by conventional means.

Fuller information about the various investigations can be obtained from the numerous technical notes, research reports and published papers of the research staff of the Association, a complete list of which is included in the annual report.

\section{INSTITUTE OF PHYSICS \\ ANNUAL REPORT FOR 1953}

$\mathrm{T}$ HE thirty-fourth annual report of the Board of the Institute of Physies, covering the work of the Institute during 1953 (obtainable from the Institute at 47 Belgrave Square, London, S.W.1), records that the Board of the Institute met six times, and its various standing committees twenty-four times, during the year. The membership increased by 248 to 4,595 . Applications for election or transfer to the various grades of membership of the Institute received during 1953 numbered 581, compared with 651 in the previous year. The degrees of a further four universities, in particular the newly established degree in applied physies of the University of Manchester and the associateship in applied physics of the Royal Technical College, Glasgow, were recognized by the Board, and two technical colleges which had applied for extension of recognition were visited by representatives of the membership and examinations committee. Seven of the thirty-two candidates for the graduateship grade of membership of the Institute were successful; for the National Certificates in applied physics the numbers of candidates continued to increase, being 151 candidates for tho ordinary level and 55 for the higher cortificate, compared with 137 and 33, respectively, in 1952. 
The circulation of the Institute's two journals, tho Journal of Scientific Instruments and the British. Journal of Applied Physics, increased during the year, and there was a further improvement in the advertisement revenue. The last three monthly issues of the 1953 volume of the Journal of Scientific Instruments were enlarged in order to reduce the delay in publication of original contributions, and provision has also been made for similar enlargement of the British Journal of Applied Physics during 1954 both to reduce delay in publication and to extend the scope of the Journal. The twelve issues of the Institute's Bulletin (issued to members only) included summaries of some of the meetings of the Education Group, the Board's reports on "Problems concerning the Education of Physicists" (afterwards re-issued as a pamphlet) and on "Summary of Salaries and Enrolments", in addition to a number of important articles based mainly on lectures delivered at meetings of the Institute. In the "Physics in Industry" series, a new volume entitled "Modern Mass Spectrometry", by Dr. G. P. Barnard, was published during the year, and the first four booklets in the new "Monographs for Students" series were issued.

The second convention of the Institute, held in Bournemouth during May 27-30, was attended by approximately 450 members and their ladies and guests ; its agenda included the thirty-third annual general meeting of the Institute, a discussion on the education of physicists and twelve group meetings, at which twenty-three papers were read. Lectures were given by Sir John Cockeroft on recent advances in nuclear physics ${ }^{1}$ and by Dr. A. C. Menzies on recent developments in applied optics ${ }^{2}$, and Canon C. E. Raven gave an evening address on the impact of physics on science and religion ${ }^{3}$.

The Institute has seven branches in Great Britain, an Indian branch under the chairmanship of Sir C. V. Raman and an autonomous Australian branch with divisions in different States. In addition to the branches in Great Britain, there are seven specialist subject groups-electronics, electron microscopy, industrial radiology, industrial spectroscopy, stress analysis, $\mathrm{X}$-ray analysis and education-which arrange their own programmes of scientific meetings and conferences. Seven specialist conferences were held by the various branches and groups, including a two-day meeting of the Industrial Radiology Group jointly with the Hospital Physicists' Association, and a conference of the X-Ray Analysis Group on film methods and microdensitometry and on identification by $\mathrm{X}$-ray analysis. As in previous years, the Institute collaborated with the University of Bristol in a summer school and conference, held at Bristol during July 13-16, on the theory of the plastic deformation of metals, and it was also associated with a conference organized by the Clarendon Laboratory, Oxford, and held there during July 18-23, on the subject of ionization phenomena in discharges. The proceedings of the conference on "Static Electrification" which was held by the Institute at Bedford College, London, during March 25-27, have been separately published ${ }^{4}$.

The Institute has been represented on many joint committees and bodies, including committees of the British Standards Institution, the Royal Society and the Parliamentary and Scientific Committee, and further details are given in the annual report. Tho Faraday Society, the Royal Meteorological Society and the British Institute of Radiology, which together with the Physical Society form the four participating societies of the Institute, have given notice of withdrawal from participation in accordance with the provisions existing in the constitution. The Physical Society is in a different position from the other three societies since its members are physicists, and will continue to have two seats on the Board of the Institute. In order to encourage members to support Science Abstracts and to enable them to continue to enjoy the privilege of purchasing copies of both Physics Abstracts and Electrical Engineering Abstracts at reduced rates in spite of increased costs of production, the Board has agreed to make a modest annual basic payment to the management committee of the abstracts from its publications account, and the Institute in return will be represented on the management committee.

This year the thirty-fourth annual general meeting of the Institute was held at the Institute's house in London on May 18, when the following were elected to take office on October 1: President, Sir John Cockeroft; Vice-President, Mr. G. R. Nookes; Honorary Treasurer, Dr. S. Whitehead; Honorary Secretary, Dr. B. P. Dudding ; New Ordinary Members of the Board, Dr. K. A. G. Mendelssohn and Mr. H. P. Rooksby. Prof. W. E. Curtis and Dr. C. Sykes (past-presidents), Mr. O. W. Humphreys, Dr. 'T. L. Ibbs and Prof. F. A. Vick (vice-presidents), Dr. H. Barrell, Dr. N. A. de Bruyne, Dr. P. H. S. Henry, Mr. A. T. Pickles, Dr. W. H. Taylor and Mr. R. G. Wood continue to serve on the Board.

${ }^{1}$ Brit. J. App. Phys., 4, 289 (1953).

${ }^{2} J$. Sci. Instr., 30, 441 (1953).

${ }^{3}$ Bull. Inst. Phys., No. 43, 75 (1953).

4 Brit. J. App. Phys., Supp. No. 2 (1953).

\section{FORESTRY IN BRITISH HONDURAS}

\section{ANNUAL REPORT FOR 1952}

r. $\mathrm{HE}$ annual report for 1952 of the Forest Depart. ment of British Honduras*, whence came the mahogany so well known in Britain during the nineteenth century, states that the Department reached thirty years of age in April 1952. The report furnishes abundant evidence of the vacillation of the authorities concerned as to the value of the Department and of the forests to the Colony. "Because of staff shortages and changes," says the report, "it was impossible to issue Forest Department Annual Reports for the years 1950 and 1951."

The Department's difficulties are mainly due to staff shortages. The post of conservator was vacant throughout the year, and two officers acted in the post. There were apparently three gazetted officers only on the staff at the end of 1952 (one on leave and one newly joined). It is scarcely surprising to read that the forest boundaries are overgrown and require reclearing and that the forest estate is at present inadequate and is also insufficiently secure: during 1952 the lease of large areas of land in the forest reserves to the Colonial Development Corporation for agricultural purposes was being negotiated. If this is the case, the legal position of the so-called forest reserves is obviously very unstable.

Finally, as can be well understood, no working plans are in force. Yet at its commencement the Department started under the most promising aus-

* British Honduras. Forest Department. Annual Report for 1952 (with Statistics in Standard Form for 1950 and 1951). Pp. 42. (British Honduras: Government Printer, 1953.) 